\title{
CORRESPONDENCE
}

\section{Whose game?}

SIR - In his review of J. Maynard Smith's Evolution and the Theory of Games, R.C. Lewontin ${ }^{1}$ refers to his own "introduction in 1961 of the apparatus of game theory into evolutionary biology". Students of the history of ideas may be interested to know that, about a week after a seminar on this subject given here by Lewontin in 1962, and shortly before R.A. Fisher's death here, the latter also gave us a seminar on the same subject. With the "characteristic modesty" to which Lewontin also refers in his review, Fisher pointed out that not only had he introduced game theory ten years before von Neumann ${ }^{2}$ but he had also discussed it in relation to evolution before Lewontin: this was in a paper that was given to the 30th session of the International Statistical Institute at Stockholm in 1957 and subsequently published twice ${ }^{3,4}$. I shall leave readers to judge for themselves the importance of these contributions but would like to record the main example that Fisher gave us at the seminar since I think it was never published and may be of widespread application to the explanation of some life cycles that are ecological enigmas. He suggested that the massive production of fruit which occurs infrequently and at random in northern deciduous forests ("'mast years") illustrated the principle that, if an opponent (in this case nut-eating animals) cannot be defeated, then it is advantageous to randomize vulnerable activities (nut-production). His biographer ${ }^{5}$ records Fisher's fondness for pigs and, since these animals used to be a:major beneficiary of mast years, I suspect that there is a connection.

\section{Botany Department, \\ University of Adelaide, \\ South Australia}

1. Lewontin, R.C. Nature 300, 113 (1982).

2. Fisher, R.A. Math. Gaz. 18, 294 (1934).

3. Fisher, R.A. Bull. Inst. Int. Stat. 36, 284 (1957).

4. Fisher, R.A. J. Ecol. 46, 289 (1958).

5. Box, Joan Fisher. R.A. Fisher, the Life of a Scientis (Wiley, New York, 1978).

\section{On Time defended}

SiR - I was interested to read the review by P.W. Atkins in the 11 November issue of Nature (p.133) criticizing On Time by Michael Shallis, since I have recently read and enjoyed the book. I found the tone of Atkins's remarks derogatory in the extreme.

A point that I would like to make is that scientists of the first category (as defined by Atkins) are so often the blinkered, passive donkeys of their professions who will deny a goodly portion of life's experiences because it is not possible to measure them quantitatively. I imagine that had Atkins been around at the time of Galileo he would have been enthusiastically pouring scorn on the "outrageous" heresy of a heliocentric planetary system for much the same reasons as he scorns Shallis's attempt to look at subject matter which is regarded as "unscientific". It is so easy to be an Atkins and to use these reductionist attitudes to stay safely within the comfortable known behaviour patterns of the peer group. It is very difficult to be a Shallis and to admit that we do not know it all and that there are areas where we can only wonder and conjecture.

I would like to know what indications Atkins has managed to find in the book that Shallis "disregards the successful continuing progress of modern science". It seems strange that Atkins should carp about this as his own popular lecture on all science rapidly coming to a single all-embracing conclusion, leaving scientists as "keepers of the truth", leaves one with the strong impression that here at least is one scientist who has come to a grinding halt and who one would expect to welcome, not deride, others whom he sees, however wrongly, as being in the same boat.

On Time is a well written, thoughtprovoking book which deserves better than to have attracted such a destructive onslaught.

V. ANN BUCKLE

Wokingham, Berks, UK

\section{Cometary record}

SIR - In my News and Views article on the recovery of Halley's Comet (Nature 25 November, p.318), I stated that Halley's Comet (at recovery $11.04 \mathrm{AU}$ away from the Sun) was the most distant comet ever seen, beating the previous record held by Comet Stearn (1927IV). I was wrong and must thank Professor R.A. Lyttleton for pointing out my error. According to S.K. Vsekhsvyatskii (Physical Characteristics of Comets), 1927IV was last seen on 13 March 1931 when it was $11.53 \mathrm{AU}$ from the Sun. So Stearn is still the record holder. For Halley to usurp its position we will have to observe it into August 1989.

DAVID W. HUGHES

Department of Physics,

University of Sheffield,

Sheffield, UK

\section{Grouping Darwin}

SIR - In his autobiography The Gates of Memory Sir Geoffrey Keynes ${ }^{1}$ revealed that the family he used to illustrate the inheritance of the ABO blood groups in his book Blood Transfusion ${ }^{2}$ was his own and his wife's. Charles Darwin was Lady Keynes's grandfather.

Of Charles and Emma Darwin's five children, four were blood-group $\mathrm{O}$ and one, George, Lady Keynes's father, was untested. Charles and Emma must therefore each have carried at least one $\mathrm{O}$ gene, and of their grandchildren, only George's children could provide further relevant information, since George's blood-type was not determined.

George's wife Maud was blood-group A, and of their four children, two were $\mathrm{O}$ (one was Lady Keynes) and two were A. Maud must therefore have been of genotype $\mathrm{AO}$, and George must have carried at least one $\mathrm{O}$ gene. In the published genealogy only the two " $O$ " children themselves have children, who therefore provide no further information about George.

The possibilities are therefore that Charles and Emma Darwin might each have been AO, $\mathrm{BO}$ or $\mathrm{OO}$, and so might their son George. For each of the nine possible genotype-pairs for Charles and Emma we can compute the probability that they had four $\mathrm{OO}$ children and a fifth who on marrying an $\mathrm{AO}$ had two $\mathrm{O}$ and two $A$ children (and hence certainly carried on $\mathrm{O}$ gene).

The calculation of these probabilities is entirely straightforward and I therefore omit the details; it should be noted that because the only person other than Charles and Emma entering the genealogy except as a child is of known genotype (Maud, who is AO), the probabilities are not functions of the unknown gene frequencies in the general population. This is, of course, unusual in this type of problem.

The resulting probabilities expressed relatively are the likelihoods ${ }^{3}$ of the several hypotheses:

\section{Relative likelihoods of Charles and Emma}

Darwin's genotypes

$\begin{array}{lr}\mathrm{OO} \times \mathrm{OO} & 16,384 \\ \mathrm{OO} \times \mathrm{AO} \text { or } \mathrm{AO} \times \mathrm{OO} & 800 \\ \mathrm{OO} \times \mathrm{BO} \text { or } \mathrm{BO} \times \mathrm{OO} & 544 \\ \mathrm{AO} \times \mathrm{AO} & 43 \\ \mathrm{BO} \times \mathrm{BO} & 19 \\ \mathrm{AO} \times \mathrm{BO} \text { or } \mathrm{BO} \times \mathrm{AO} & 26\end{array}$

It will be seen that it is overwhelmingly likely that both Charles and Emma Darwin were blood-group $\mathrm{O}$, the next most likely hypotheses being over 20 times less likely.

A.W.F. EDWARDS

School of Clinical Medicine,

University of Cambridge, $U K$

\section{Keynes, G. The Gates of Memory (Clarendon, Oxford, 1981) \\ 2. Keynes, G. Blood Transfusion (Frowde and Hodder \& Stoughton, London, 1922). \\ 3. Edwards, A.W.F. Likelihood (Cambridge University Press, 1972)}

\section{Acidity and alkalinity}

SIR - "Acidity" is an awkward term when used as a heading for discussion of effects brought about by varying hydrogen ion concentration. It is limiting in first appearances because it also doubles in general usage as a term implying only the acid end of the scale. The older term "hydrogen ion concentration" does not itself convey the concept we are often trying to put across; that which we neatly sum up in the jargon term " $p \mathrm{H}$ ".

When we are heading manuscript sections for variables such as "temperature",

"pressure" and so on, the heading word " $p H$ " seems too short. We tend to get around the problem by writing "effect of $p \mathrm{H}$ ". Some manoeuvring is also required to ensure that we do not have $p \mathrm{H}$ as the first word of a sentence, since we cannot capitalize it.

For the parallel concept of oxidation and reduction we rarely use the symbol " $E$ ", meaning the oxidation-reduction potential, in a sentence. Certainly the phrase "transferable electron potential" is an unusual heading. The convenient word "redox" has come into common use.

Therefore, by analogy, I propose the term "alkacidity" as a convenient word to express an important idea in brief.

Pfter Meredith

Christchurch,

New Zealand 